\title{
CATTLE EGRETS AND NESTS FOUND DURING FRANKLIN'S GULL SURVEYS IN SASKATCHEWAN IN 2006 AND 2007
}

G. W. BEYERSBERGEN, Environment Canada, Canadian Wildlife Service, Room 2004999 - 98 Avenue, Edmonton, AB, T6B 2X3.

The Cattle Egret occurs with some regularity in prairie Canada and the first recorded observation of Cattle Egrets in Saskatchewan was 14-17 June 1974 at Eyebrow Lake.6, 8 The first breeding record for Saskatchewan, 30 June 1981, was a pair nesting in a tree in a heronry occupied by Great Blue Herons and Black-crowned Night-Herons on Old Wives Lake. ${ }^{4,7,8}$ The second breeding record was at Eyebrow Lake in $1994 .^{8}$ In 2005, a pair of Cattle Egrets displaying breeding behaviour was observed on 4 June at Stalwart Marsh National Wildlife Area (NWA) near Last Mountain Lake (Dave Duncan, Canadian Wildlife Service (CWS), pers. comm.). Phil Taylor (CWS, pers. comm.), confirmed breeding on 7 June at Stalwart Marsh NWA with the discovery of four nests perched in the Common Reed Grass and bulrush (Scirpus sp.) stands. This article reports Cattle Egret observations made in the spring and summer of 2006 and 2007 during surveys of Franklin's Gull colonies by my field crew and myself at Stalwart Marsh NWA, Middle Quill Lake and Goose Lake.

\section{Stalwart Marsh NWA}

On our visit to Stalwart Marsh NWA on 20 May 2006, we found the water levels were very high, flooding and destroying most of the bulrush stands in the basin and effectively eliminating the majority of the nesting habitat for colonial waterbirds, including the Cattle Egret. On that day we observed a single Cattle Egret walking along the shoreline of Stalwart Marsh in the basin where the birds nested in 2005 .

Our next visit to Stalwart Marsh NWA was on 18 May 2007. Water levels were as high or higher than in the previous year and there was limited emergent vegetation around the perimeter of the basin. No Cattle Egrets were observed in the area that day.

\section{Middle Quill Lake}

During a visit to Middle Quill (Mud) Lake on 17 May 2006 to map the boundary of the Franklin's Gull colony within the bulrush habitat, we observed three adult Cattle Egrets flush from the bulrushes. On the next visit on 14 July, I observed over 50 adult Cattle Egrets flying above the colony's bulrush stand. I found nests on what appeared to be the edge of a Cattle Egret colony with two nests containing three and five eggs respectively. To reduce disturbance to the Cattle Egret colony, I did not search for or check other nests, although more were visible. No photos were taken of the nests or nesting colony. Assuming that all the adults flying above the colony were off their nests, then there would be a minimum of 25 pairs or nests in the colony. It is 




Figure 1. Cattle Egret nests in willow at Middle Quill Lake, SK on 13 June 2007.

G. Beyersbergen

also possible that the flock of Cattle Egrets observed by numerous observers beginning in early August at the Borsheim wetland 85 kilometres to the southwest came from the Middle Quill Lake colony. ${ }^{2}$

On 19 May 2007, when we next visited Middle Quill Lake, water levels were extremely high and the bulrush stand where the Cattle Egrets had nested in 2006 was completely submerged. Six adult Cattle Egrets were feeding along the shoreline at the access point on the east side. About $100 \mathrm{~m}$ south of the access road, a minimum of 38 Black-crowned NightHerons were nesting in a flooded willow stand. On 13 June 2007, we revisited the site and found the water levels had dropped slightly but were still high. We accessed the willow stand using a canoe and found six Cattle Egret nests, a minimum of 1.5 metres above ground, with recently abandoned eggs (Figures 1 and 2). No adult Cattle Egrets 


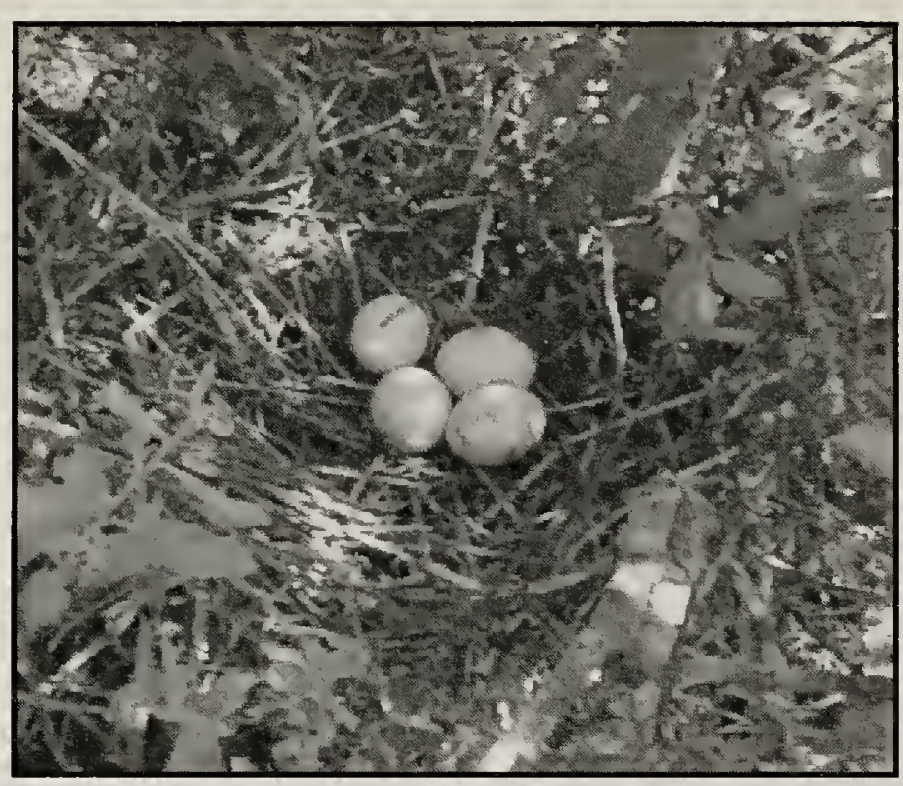

Figure 2. Cattle Egret nest at Middle Quill Lake, SK on 13 June 2007.

G. Beyersbergen

were at the heronry or in the immediate vicinity. There also were no adult Blackcrowned Night-Herons, but there were several dead or starving Black-crowned Night-Heron nestlings along with numerous predated eggs among 20 stick nests. It appears the Blackcrowned Night-Herons shifted their colony to the bulrush stand about 200 metres north, where Franklin's Gulls, Western Grebes, and Eared Grebes were nesting, but no Cattle Egrets could be found. A third visit to the site on 17 July 2007 also failed to locate any Cattle Egrets. However, four adult Great Egrets were observed in the Blackcrowned Night-Heron colony in the bulrush stand. We visited the Blackcrowned Night-Heron colony by canoe but found no nesting activity of the Great Egrets.

\section{Goose Lake}

Several visits were made to Goose Lake in 2006 and on 18 July we noted a single Cattle Egret along the road near the shore of the east bay of the lake.

During the initial survey of the Franklin's Gull colony on 12 June 2007, we located a nest with four eggs (Figure 3 ) in the bulrush stand along with four Black-crowned Night-Heron nests.

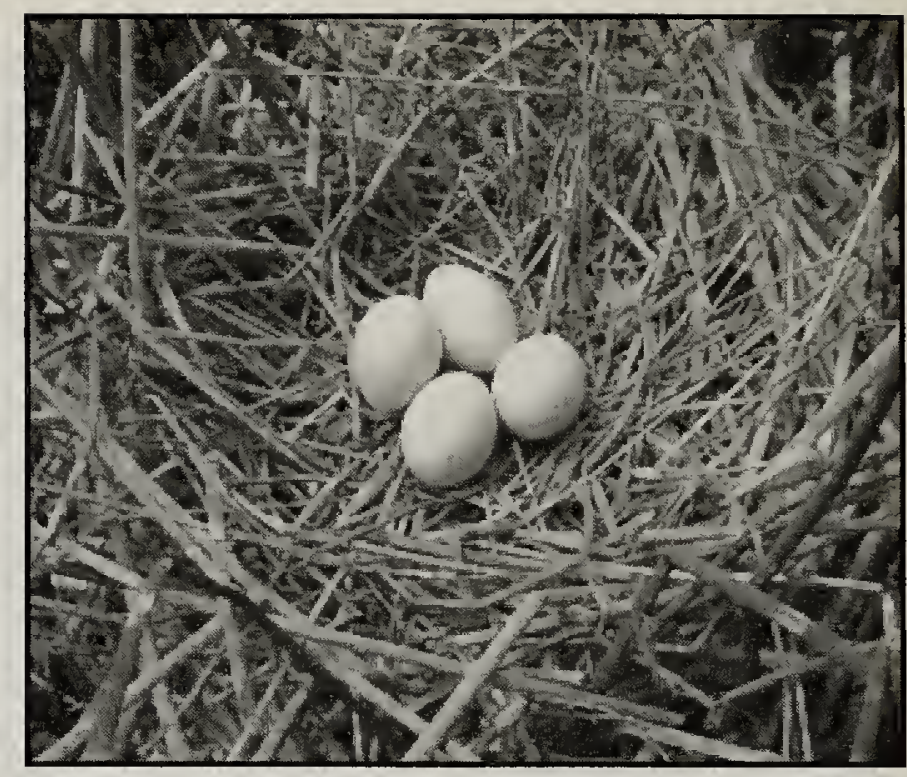

Figure 3. Cattle Egret nest at Goose Lake, SK on 12 June 2007

G. Beyersbergen

When we checked the nest on 15 July 2007 there were three young (Figure 4) and three adult Cattle Egrets in attendance at the nest site.

Our observations confirm that the range of the Cattle Egret continues to expand northwards in prairie Canada. In Alberta, although there are observations as far north as Jessie Lake, latitude: $54^{\circ} 15^{\prime} \mathrm{N}$, in 1994 and

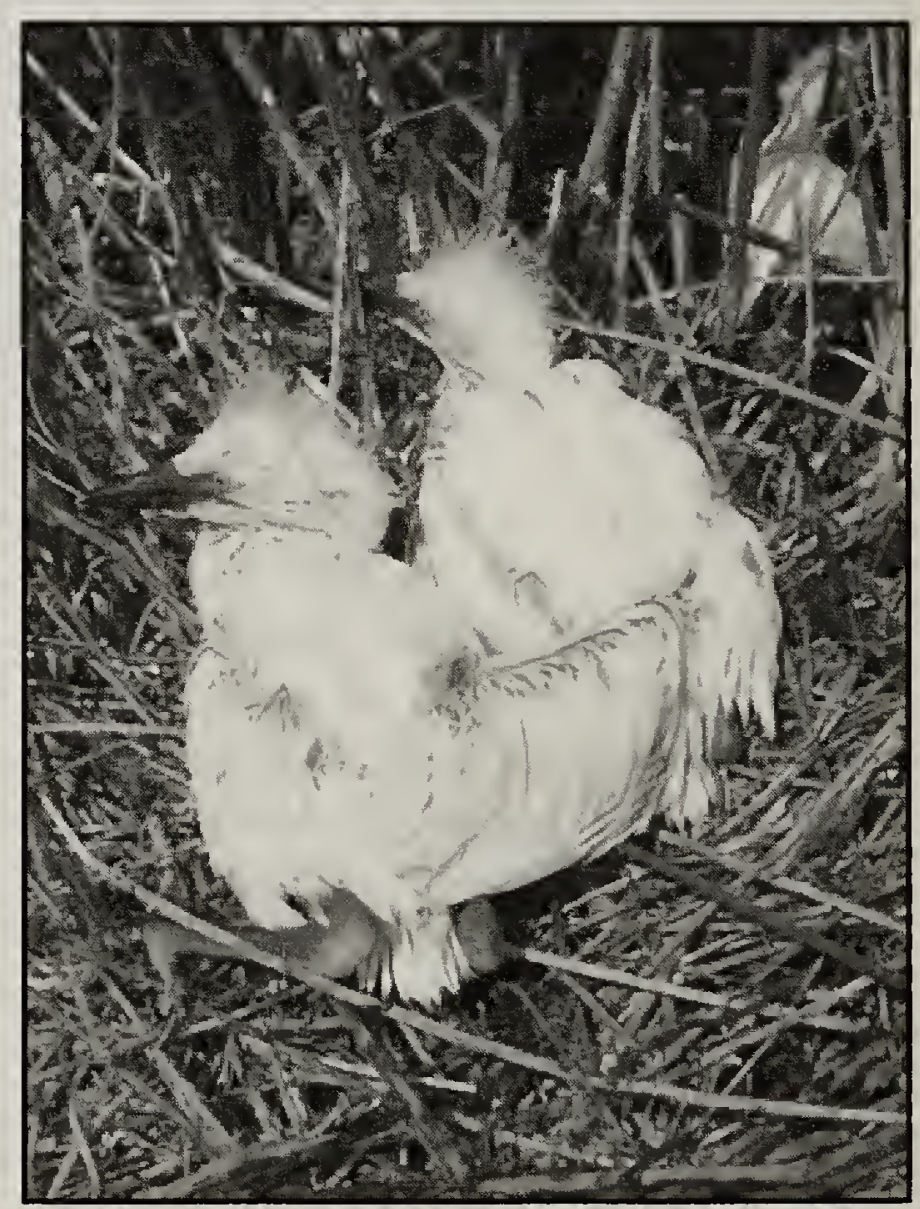

Figure 4. Cattle Egret young in nest at Goose Lake, SK on 15 July 2007

G. Beyersbergen 
the latest observation near Carseland in 2003,5 the Cattle Egret is still classified as an Accidental/Vagrant species with no documented nesting in the province. ${ }^{3}$ Manitoba's first documented nesting record was 1 September 2005 at Plum Lake, latitude: $49^{\circ} 38^{\prime}$ N. ${ }^{1}$ In Saskatchewan, we now have documented nesting to the west of centre, with a single nest at Goose Lake, latitude: $51^{\circ} 45^{\prime} \mathrm{N}$ and to the east, with a colony at Middle Quill Lake, latitude: $51^{\circ} 56^{\prime} \mathrm{N}$, which is the most northerly documented occurrence of breeding in the prairie region. Further studies and surveys of prairie region wetlands for waterbird nesting will continue to add to our knowledge of the Cattle Egret in our area.

Acknowledgments: Thanks to Bev Gingras, Wendy Calvert, Gillian Turney, Robin Bloom, Martin Schmoll and Lisa Mathias for their perseverance during the long Franklin's Gull surveys in Saskatchewan during which all of these rare sightings were recorded. Review of the manuscript by Wendy Calvert and Ron Bazin provided many helpful improvements.
1. BAZIN, R. 2006. First documented breeding records of Cattle Egrets in Manitoba. Blue Jay 64(3): 126-130.

2. DICKSON, R, A.R. SMITH and P.S. TAYLOR. 2007. Status of wading birds (Ardeids and Ibises) at the north end of Last Mountain Lake in 2006. Blue Jay 65 (2): 67-77.

3. FEDERATION OF ALBERTA NATURALISTS. 2007. The Atlas of Breeding Birds of Alberta: $A$ second look. The Federation of Alberta Naturalists, Edmonton, Alberta. 626 pp.

4. GOLLOP, J.B. 1981. Nesting season. Prairie Provinces region. American Birds 35(6): 950-952.

5. HUDON, J, R. KLAUKE, R. KNAPTON, M.R. LEIN, J. RIDDELL, B. RITCHIE and R. WERSHLER. 2007. Seventh Report of the Alberta Bird Record Committee. Nature Alberta 37 (2): 31-33.

6. HOUSTON, C.S., and M.I. HOUSTON. 1974. The nesting season: June 1, 1974 - July 31, 1974, Northern Great Plains. American Birds 28(5): 915-918.

7. RONEY, K. 1982. Cattle Egret nesting record for Saskatchewan. Blue Jay 40 (3): 163-164.

8. ROY, J.F. 1996. Birds of the Elbow. Special Publication Number 21. Saskatchewan Natural History Society (Nature Saskatchewan). Regina, Saskatchewan. 325 pp.

\section{FIRST RECORD OF CASSIN'S VIREO FOR SASKATCHEWAN}

ALAN R. SMITH, Box 154, Avonlea, SK, SOH OC0 and PHILIP S. TAYLOR, Canadian Wildlife Service, 115 Perimeter Road, Saskatoon, SK, S7N 0X4

On 24 May 2002, the first author extracted an unusual bird from one of the 13 mist nets used in migration monitoring studies at the Last Mountain Bird Observatory (LMBO). The bird seemed to be an unusually pale Blueheaded Vireo, features that begged its consideration as a Cassin's Vireo or even a Plumbeous Vireo. As with any capture at $\mathrm{LMBO}$, the bird was taken to the lab, weighed and measured, and given a numbered United States Fish and Wildlife Service aluminum band. As the bird had yet to be identified, Smith called the second author, who was working at Last Mountain Lake National Wildlife Area, to help document and photograph the bird before it was 